\title{
IMPACT OF IMPROVED SEEDS ON SMALL FARMERS' PRODUCTIVITY, INCOME AND LIVELIHOOD OF BARA LOCALITY IN NORTH KORDOFAN STATE, SUDAN
}

\author{
Elkhalil Elnour Briema Ahmed, Researcher \\ Elobeid Agricultural Research Corporation, Sudan \\ Maryoud Elnow Maryoud, Associate Professor \\ Faculty of Natural Resources \& Environmental Studies, University of Kordofan, Sudan \\ Elrashied Elimam Elkhidir, Associate Professor \\ College of Agricultural Studies, Sudan University of Science \& Technology, Sudan \\ Tarig Elsheikh Mahmoud, Associate Professor \\ Gum Arabic Research Centre, University of Kordofan, Sudan \\ E-mail: rashiedimam@sustech.edu
}

\begin{abstract}
This study was designed to test and identify the impact of improved seeds on small farmers' productivity, income and livelihood in Bara locality. Sixty households participants were randomly selected through a field survey during 2011 for 2008/2009, 2009/2010 and 2010/2011 cropping seasons. The study applied Multi-stage random sample technique. Based on existing farm situation and price level, the sampled farmers were obtained SDG 8604 as gross margin to cover all expenses. Results of this study also depicted that the required net income and off-farm income were 16293 and 11378 SDG, respectively. With respect to Linear Programming (LP) results, a total of SDG 8890 were obtained and all crops were entered and solved. The optimal plan and existing farm situation were changed by 3.3 and $5.6 \%$ for gross margin and cash income, respectively. Results of LP also indicated a positive change in production patterns of resource use; 3.3, 6.2, 3.5, 3.3 and $9.1 \%$ for land, cash income, labour, seeds supply and productivity, respectively under existing and optimal plan. Partial crop budgeting revealed that, all treatments were financially gave positive returns. Dominance analysis showed that cowpea ainelgazal, okra, roselle and sesame herhri crops were dominated by crops of millet ashana, watermelon, groundnut and guar, respectively. Marginal analysis exposed that, for every SDG 1.00 invested in improved seeds cultivation, farmer can expect to cover the SDG 1.00 and obtain an additional SDG 1.345; then, additional seed rate implies a further marginal rate of SDG 43.9. Sensitivity analysis for cost over run and benefit reduction by $10 \%$ indicated highly stability with MRR of $1.22,3.991$ and 1.21 and $3.951 \%$ for watermelon and guar, respectively. The productivity of improved seeds compared to local ones was increased in some varieties and decreased among others. This study reached to some recommendations for improving crop productivity, production and livelihood of small farmers in Bara locality.
\end{abstract}

\section{KEYWORDS}

Linear programming; Dominance; Marginal analysis; Roselle; Sesame; Millet; Watermelon; Groundnut; Guar.

North Kordofan state is located between latitudes $11-16^{\circ} \mathrm{N}$ and longitudes $27-32^{\circ} \mathrm{E}$. Bara locality lies between latitudes $13-14^{\circ} \mathrm{N}$ and longitudes $28-31^{\circ} \mathrm{E}$. The State faces a number of complex and interconnected problems such as environmental, socio-economical and political problems. The majority of small farmers in Bara locality experience a situation of food insecurity, which is mainly attributed to successive crop failures. The project area was selected by the proceeding IFAD mission in the consultation process with federal and state government for its concentration of deprived population, relative lack of development but reasonable potential (IFAD, 1999). Improved seeds can achieve its purpose only if it is transferred to and adopted by farmers. Effective technology of improved seeds can result in higher agricultural production and increased incomes of farming families, which has positive impact on rural poverty. Improved crop yields will reduce costly imports of agricultural commodities and the cost of production of basic raw materials for agro-industries. In the long run the adoption of improved seed technology by farmers can make agro-industries more 
competitive in the international markets (Bauer, 2004). Hazell (1986) reported that linear programming model is a method of determining a profit maximization combination of farm enterprises that is feasible with respect to a set of farm constraints. Grover et al., (2004) applied linear programming (LP) model to test the impact of improved seeds and the model was specified in terms of its objective function, activities and constraints under normal conditions to determine the optimum resource allocation for specific activities for improving the income level at the household level. Partial crop budgeting is another tool to determine the costs and benefits of the various alternatives (Cymmit, 1988). Ultimate goal of this research was to determine the relationship between improved seeds and farmers' productivity, income and livelihood. This study hypothesized that investors would get the benefit when grow improved seeds.

\section{ECONOMETRIC METHODOLOGY}

Households' survey questionnaire regarding crop production activities was developed and tested in pre-survey to collect primary data through direct interviewing with IFAD farmers. A form of multistage random sampling of 60 respondents was selected covering ten villages of the two administrative units (Rural Bara and Tayba). Data were analyzed using descriptive analysis, linear programming model (LP), partial crop budgeting, dominance, and marginal and sensitivity analyses. Relevant secondary sources of data were used.

Linear programming model. Pomeroy et al., (2005) stated that linear programming requires the information of the farm and non-farm activities and options with their respective resource requirements and any constraints on their production, the fixed requirements and other maximum, minimum constraints that limit family or farm production, cash costs and returns of each activity and defined objective function. In this context, a linear programming model has been developed to determine the area to be used for different crops for maximum contribution and for improving farmers' income. The model expressed as follows:

Objective equation:

$$
\text { Maximise } Z=\sum_{j=1} C_{j} X_{j}
$$

Subject to:

$$
\sum_{j=1} a_{i j} X_{j} \leq b_{i=1 \text { ton }}
$$

$X \mathrm{j} \geq 0$ all $\mathrm{j}=1$ to $m$ non-negativity constraint activities

where:

$$
\begin{aligned}
& Z=\text { Gross margin } \\
& C_{j}=\text { Price of production activities } \\
& X_{j}=\text { level of } j^{\text {th }} \text { production activity } \\
& a_{i j}=\text { the } i^{\text {th }} \text { resource required for a unit of } j^{\text {th }} \text { activity } \\
& b_{i}=\text { the resource available with the sample farmers } \\
& j=\text { refers to number of activities from } 1 \text { to } n \\
& i=\text { refers to number of resources from } 1 \text { to } m
\end{aligned}
$$

Constraints:

(i) Land: where:

$$
\sum a_{i j} X_{j} \leq O L \text { and } \sum a_{i j} X_{j} \leq R L
$$

$\mathrm{OL}$ and $\mathrm{RL}$ are the size of holding owned and rented land, respectively. 
(ii) Family labour:

$$
\sum a t_{j}-h t X_{j} \leq L t, h t X_{j} \leq A t
$$

where:

Lt and $A t=$ available family labour and hired labour in the $t^{\text {th }}$ period.

$\mathrm{ht}=$ is the amount of hired labour required in the $\mathrm{t}^{\text {th }}$ period for $\mathrm{j}^{\text {th }}$ activity.

$A t_{j}=$ is the amount of labour required in the $t^{\text {th }}$ period for $\mathrm{j}^{\text {th }}$ activity.

(iii) Working capital:

$$
\sum \mathrm{k}_{\mathrm{ij}} \mathrm{X}_{\mathrm{j}} \leq \mathrm{WK}
$$

where:

WK $=$ is the amount of available working capital.

$\mathrm{K}_{\mathrm{ij}}=$ is the amount of working capital required for production and non production activities.

Working capital is the value of inputs (purchased or owned) allocated to an enterprise with the expectation of a return at a later point. The cost of working capital is the benefit given up by the farmer by trying up the working capital in the enterprise for a period of time (Cimmyt, 1988).

(v) Seed supply:

$$
\sum P_{i} X \leq I M P S
$$

where:

IMPS = is the amount of improved seeds supply available with the sample farmers. $P_{i j}=$ is the amount of seed supply required for production activities.

(vi) Crop Productivity:

$$
\sum S_{i j} \leq P D
$$

where:

$P D=$ is the amount of seed productivity available with the sample farmer. $S_{i j}=$ is the amount of seed productivity required for production activities.

General formula of objective function:

$$
\text { Maximize } Z=a X_{1}+b X_{2}+c X_{3}+d X_{4}+e X_{5}+\mathrm{fX}_{6}+g X_{7}+h X_{8}+i X_{9}+j X_{10}+k X_{11}+I X_{12}
$$

where:

$a, b, c, d, e, f, g, h, I, j, k$ and I are coefficients of objective function.

General formula of the inequalities:

$$
a X_{1}+b X_{2}+c X_{3}+d X_{4}+e X_{5}+f X_{6}+g X_{7}+h X_{8}+i X_{9}+j X_{10}+k X_{11}+I X_{12} \leq R H S
$$

where: a, b, c, d, e, f, g, h, i, j, k and I are the coefficient of the constraints inequalities and $\mathrm{RHS}$ is the right hand side.

The improved production activities and decision variables used in the study are: $\mathrm{X}_{1}=$ Millet ashana, $X_{2}=$ Cowpea ainelgazal, $X_{3}=$ Okra Khartoum-red, $X_{4}=$ Roselle $X_{5}=$ Watermelon cashair, $X_{6}=$ Sesame hirhri, $X_{7}=$ Groundnut sodri, $X_{8}=$ Guar improved. 
Farm model. This model was conducted to identify and analyze the empirical crop-mix problem of farmer who has to allocate his fixed resources like land, labour and working capital for different crops. The link between the tableau and algebraic formulations of the model can be illustrated as: eight crops can be grown and each of which has specified per hectare requirements. Production of one hectare requires $3,5,5,5,5,4,4,4$, and 4.4, 33, $32,9,9,26,57$, and 21 , man hours and working capital for the above decision variables, respectively. A total of 60 man hours of labour is potentially available, being the amount provided by family workers during season. The activity gross margins in the objective function are differed for each unit hectare (Table 1).

Partial crop budgeting. Partial budgeting technique was used for the analysis of data. The technique involved selecting of those costs that vary with particular treatment being analyzed and the net benefits of each treatment (Mahmood et al., 2000).

Table 1 - Linear programming tableau

\begin{tabular}{|c|c|c|c|c|c|c|c|c|c|}
\hline Row name & $\mathrm{X}_{1}$ & $\dddot{x}_{2}$ & $\mathrm{X}_{3}$ & $x_{4}$ & $\mathrm{X}_{5}$ & $\mathrm{X}_{6}$ & $\mathrm{x}_{7}$ & $\mathrm{X}_{8}$ & RHS \\
\hline Objective function Max $Z$ & 989 & 92 & 57 & 701 & 1648 & 361 & 2105 & 2653 & \\
\hline \multicolumn{10}{|l|}{ Resources (constraints): } \\
\hline Land/ha & 1 & 1 & 1 & 1 & 1 & 1 & 1 & 1 & 7 \\
\hline Labour/MH & 3 & 5 & 5 & 5 & 5 & 4 & 4 & 4 & $60^{\circ}$ \\
\hline Working capital/SDG & 4.4 & 33 & 32 & 9 & 9 & 26 & 57 & 21 & 2007 \\
\hline Seed supply $\mathrm{kg} / \mathrm{ha}$ & 4 & 0.4 & 0.2 & 0.2 & 0.4 & 0.8 & 40 & 0.1 & 48 \\
\hline Productivity $\mathrm{kg} / \mathrm{ha}$ & 71 & 60 & 30 & 92 & 98 & 84 & 205 & 101 & 741 \\
\hline Average cultivated area/ha & 1 & 0.26 & 0.11 & 0.67 & 2.73 & 1.1 & 0.18 & 0.80 & 3 \\
\hline
\end{tabular}

Source: Field survey, 2011. SDG: Sudanese Gienh.

Dominance analysis. Dominance analysis is carried out in order to rank the treatments in order of increasing costs that vary. Any treatment has net benefits that are less than or equal to those of treatment with lower cost that vary i9s dominant (marked with D).

Marginal analysis. Marginal analysis is conducted to know returns to investment and thus the less benefited treatments were eliminated by making the use of dominance analysis. Marginal rate of return indicate what farmers can expect to gain, on average, in return for their investment when they decide to change from one practice to another (Cymmit, 1988). Marginal values were calculated as:

$$
\text { Marginal rate of returns }(M R R)=\frac{\text { Incremental net benefits }}{\text { Incremental net costs }} X 100 \%
$$

Maximizing TPP:

when:

$$
\frac{\partial \mathrm{TPP}}{\partial \mathrm{x}}=\mathrm{MPP}=0
$$

where:

TPP $=$ Total physical productivity (output price per unit).

MPP = Marginal physical productivity.

$\mathrm{x}=$ Input used (cost price per unit).

Sensitivity analysis. The sensitivity analysis was done to check risk factors which cause price variability. The analysis was done assuming costs over run by $10 \%$ keeping the benefits same, and then by assuming benefits reduction by $10 \%$ keeping costs same.

Crop productivity. Productivity is the amount of output per unit of input. It refers to the volume of output produced from a given volume of inputs or resources. Productivity used to know and explore the trend of improved seeds versus local. 


\section{RESULTS AND DISCUSSION}

The existing farm situation of small holders was estimated in order to explore the potential for improvement in agricultural production, productivity, labour use efficiency and hence the gross margins per unit of land at household micro level. Farmers derived income from both farm and non-farm activities. Based on the existing farm situation and prevailing price levels, the sample farmers were obtaining SDG 8604 as gross margin to cover all expenses including subsistence and livelihood requirements and hired labour expenses. Results revealed that, farmers obtained net cash income and off-farm income of SDG 16293 and 11378 , respectively (Table 2 ).

Table 2 - Sources of cash income and expenses of the sampled farmers (Averages taken from $2008 / 2009$ to $2010 / 2011$ ) in SDG

\begin{tabular}{|c|c|}
\hline Particulars & $\mathrm{SDG}^{*}$ \\
\hline 1. Gross margin: & 8604 \\
\hline 1.1 Improved seed & 8604 \\
\hline 2. Off-farm income & 11378 \\
\hline 3. Total income $(1+2)$ & 19982 \\
\hline 4. Expenses: & 3689 \\
\hline 4.1 Subsistence & 3498 \\
\hline 4.2 Hired labour & 191 \\
\hline Farm cash income $(1-4.1)$ & 5106 \\
\hline Net cash income $(3-4)$ & 16293 \\
\hline
\end{tabular}

Source: Field survey, 2011.

*One US\$ $=5.2$ SDG.

Based model was solved and the algebraic versions depend on linear programming model. With respect to unit area hectare, the results of optimal solution or farm plan for crops indicated that all crops were optimally emerged with a total gross margin of SDG 8890 . Watermelon and guar were the most profitable with gross margin of SDG 4496 and 2130 , respectively (Table 3 ).

Table 3 - Optimal solution or farm plan for the base model in SDG/ha

\begin{tabular}{|c|c|c|c|}
\hline Improved crop & Unit Area/ha & Objective coefficient & Optimal solution \\
\hline Millet ashana & 1 & 989 & 989 \\
\hline Cowpea ainelgazal & 0.26 & 92 & 24 \\
\hline Okra Khartoum-red & 0.11 & 57 & 6 \\
\hline Roselle improved & 0.67 & 701 & 469 \\
\hline Watermelon cashair & 2.73 & 1647 & 4496 \\
\hline Sesame hirhri & 1.1 & 360 & 396 \\
\hline Groundnut sodri & 0.18 & 2105 & 379 \\
\hline Guar improved & 0.803 & 2653 & 2130 \\
\hline Final value & -1 & - & 8890 \\
\hline
\end{tabular}

Source: Field survey, 2011.

Farm income upon the optimal plan under reallocation of resources indicated an improvement in gross margin and cash income per hectare by $3.3 \%$ and $5.6 \%$ or by 0.033 and 0.056 units, respectively (Table 4).

Resource productivity in terms of gross margin for land, cash income, labour, seed supply and productivity were increased in optimal plan by $3.3 \%, 6.2 \%, 3.5 \%, 3.3 \%$, and $9.1 \%$, respectively; over existing farm situation. The available labour productivity of gross margin per man hour $(\mathrm{GM} / \mathrm{MH})$ was the total of man equivalent for the representative farm (Table 5).

Partial crop budgeting showed that all improved crops gave positive returns, this is actually due to higher field prices and lower costs of production in such seasons (Table 6). 
Table 4 - Change in farm income under optimal base model over existing plan

(Sample holdings from 2008/2009 to 2010/2011 cropping seasons) in SDG

\begin{tabular}{|c|c|c|c|}
\hline Particulars & \multicolumn{2}{|c|}{ Existing Optimal value } & $\%$ increment \\
\hline Gross margin & 8604 & 8890 & 3.3 \\
\hline Subsistence & 3498 & 3498 & \\
\hline Cash income & 5106 & 5392 & 5.6 \\
\hline
\end{tabular}

Source: Field survey, 2011.

Table 5 - Marginal value productivities of various resources under existing and optimal plan (Sample holding from 2008/2009 to 2010/2011 cropping seasons) in SDG

\begin{tabular}{|c|c|c|c|}
\hline Particular & Existing & Optimal value & $\%$ increment \\
\hline Land $\mathrm{Gm} / \mathrm{ha}$ & 1229 & 1270 & 3.3 \\
\hline Cl/ha & 1.6 & 1.7 & 6.2 \\
\hline Labour Gm/MH & 143 & 148 & 3.5 \\
\hline Seed supply Gm/ha & 179 & 185 & 3.3 \\
\hline Productivity $\mathrm{Gm} / \mathrm{ha}$ & 11 & 12 & 9.1 \\
\hline
\end{tabular}

Source: Field survey, 2011. GM: Gross margin, ha: hectare.

Table 6 - Partial crop budgeting for different improved crops in Bara Locality (Averages taken from 2008/2009 to 2010/2011cropping seasons) in SDG

\begin{tabular}{|c|c|c|c|c|c|}
\hline Improved variety & $\begin{array}{l}\text { Yield } \\
\mathrm{kg} / \mathrm{ha}\end{array}$ & $\begin{array}{l}\text { Adjusted yield } \\
\mathrm{kg} / \mathrm{ha}\end{array}$ & $\begin{array}{c}\text { Gross field benefit } \\
\text { SDG/ha }\end{array}$ & $\begin{array}{l}\text { Total costs } \\
\text { SDG/ha }\end{array}$ & $\begin{array}{c}\text { Net } \\
\text { benefit } \\
\text { SDG/ha }\end{array}$ \\
\hline Millet ashana & 71 & 57 & 789 & 19 & 770 \\
\hline Okra Khartoum-red & 30 & 24 & 90 & 26 & 64 \\
\hline Cowpea ainelgazal & 60 & 48 & 68 & 24 & 44 \\
\hline Roselle improved & 92 & 74 & 542 & 55 & 487 \\
\hline Sesame hirhri & 84 & 67 & 279 & 161 & 118 \\
\hline Watermelon cashair & 98 & 78 & 1305 & 239 & 1066 \\
\hline Groundnut sodri & 205 & 164 & 1673 & 541 & 1132 \\
\hline Guar improved & 101 & 81 & 2122 & 551 & 1571 \\
\hline
\end{tabular}

Source: Field survey, 2011. Total costs include: Costs of seeds, costs of seed dressing, costs of insecticide, cash labor and family labor, costs of by-product and rental costs in SDG/ha.

Dominance analysis revealed that okra khartoum-red, cowpea ainelgazal, roselle and sesame herhri were dominated and eliminated by millet ashana, watermelon cashair, groundnut sodri and guar, while the net field benefit were highest for T8 (Guar improved), followed by T7 (Groundnut Sodri), T6 (Watermelon Cashair) and T1 (Millet Ashana). Therefore, these treatments were accepted as the best (Table 7).

Bearing in mind the minimum acceptable rate of returns was assumed to be $100 \%$. Analysis of marginal rate of returns revealed that, T6 was higher than minimum acceptable rate of returns. However T6 and T8 were emerged as the best among the alternatives, thus every SDG 1.00 invested in improved seeds cultivation, farmer can expect to recover the SDG 1.00 and obtained additional SDG 1.345. Hence, increasing seed rate implies a further marginal rate of SDG 43.9 (Table 8).

Table 7 - Dominance analysis of improved seeds in SDG hectare

\begin{tabular}{|c|c|c|}
\hline Treatments & Total costs & Net field benefits \\
\hline T1 Millet ashana & 19 & 770 \\
\hline T2 Cowpea ainelgazal & 24 & $44 \mathrm{D}$ \\
\hline T3 Okra Khartoum-red & 26 & $64 \mathrm{D}$ \\
\hline T4 Roselle improved & 55 & $487 \mathrm{D}$ \\
\hline T5 Sesame herhri & 161 & $118 \mathrm{D}$ \\
\hline T6 Watermelon cashair & 239 & 1066 \\
\hline T7 Groundnut sodri & 541 & 1132 \\
\hline T8 Guar improved & 551 & 1571 \\
\hline
\end{tabular}

Source: Field survey, 2011. 
Table 8 - Marginal analysis of improved seeds in SDG per hectare

\begin{tabular}{|c|c|c|c|c|c|}
\hline Treatments & Total costs & Marginal costs & Net field benefits & Marginal net field benefit & $\mathrm{MRR}=\mathrm{V} / \mathrm{IIII}^{*} 100 \%$ \\
\hline 1 & II & III & IV & V & \\
\hline $\mathrm{T}_{1}$ & 19 & $\cdots$ & 770 & $\begin{array}{ll}\cdots \\
-\end{array}$ & - \\
\hline $\mathrm{T}_{6}$ & 239 & 220 & 1066 & 296 & 134.5 \\
\hline$T_{7}$ & 541 & 302 & 1132 & 66 & 22.0 \\
\hline$T_{8}$ & 551 & 10 & 1571 & 439 & 4390 \\
\hline
\end{tabular}

Source: Field survey, 2011.

The sensitivity analysis of costs over run ensured that treatment six and eight significantly remain same (watermelon and guar) and thus T8 was considered as the best with MRR 3991\% and T6 rank second with MRR 122.3\% (Table 9).

Table 9 - Sensitivity of marginal analysis for costs over run in SDG per hectare

\begin{tabular}{|c|c|c|c|c|c|}
\hline Treatments & Total costs & Marginal costs & Net field benefits & Incremental net benefits & $\mathrm{MRR}=\mathrm{V} / \mathrm{II} \mathrm{I}^{*} 100 \%$ \\
\hline 1 & II & III & IV & $\mathrm{V}$ & \\
\hline $\mathrm{T}_{1}$ & 20.9 & - & 770 & - & \\
\hline $\mathrm{T}_{6}$ & 262.9 & 242 & 1066 & 296 & 122.3 \\
\hline $\mathrm{T}_{7}$ & 595.1 & 329.2 & 1132 & 66 & 20.0 \\
\hline $\mathrm{T}_{8}$ & 606.1 & 11 & 1571 & 439 & 3991 \\
\hline
\end{tabular}

Source: Field survey, 2011.

Sensitivity analysis that assumed benefits reduction; indicated that T6 and T8 were the best among alternative with MRR $121.1 \%$ and $3951 \%$. Based on the analysis of partial budget T8 was highly stable (Table 10). In spite of low rainfall, pests and diseases damage, productivity of improved seeds trend versus local goes further in some varieties and declined in others.

Table 10 - Sensitivity of marginal analysis for benefits reduction in SDG per hectare

\begin{tabular}{|c|c|c|c|c|c|}
\hline Treatments & Total costs & Marginal costs & Net field benefits & Incremental benefits & $M R R=V / I I I^{*} 100 \%$ \\
\hline 1 & II & ili & IV & $\mathrm{V}$ & \\
\hline$T_{1}$ & 19 & $\cdots \cdots$ & 693 & (n) & $-\ldots$ \\
\hline $\mathrm{T}_{6}$ & 239 & 220 & 959.4 & 266.4 & 121.1 \\
\hline$T_{7}$ & 541 & 302 & 1018.8 & 59.4 & 19.7 \\
\hline $\mathrm{T}_{8}$ & 551 & 10 & 1413.9 & 395.1 & 3951 \\
\hline
\end{tabular}

Source: Field survey, 2011.

\section{CONCLUSION}

Analysis of data showed that improved seeds were most economically for growers. The optimal base model showed improvement in gross margin, farm income, resource use, and production patterns. Partial crop budgeting revealed that, all improved crops financially gave positive returns. Marginal rate of returns revealed that farmer can benefit from improved seed. Sensitivity analysis founded that treatment five and seven were highly stable. Crop productivity trend goes up in some improved varieties compared to the local ones.

\section{REFERENCES}

[1] Bauer, S. and Karki, L. (2004). Rural poverty reduction through research for development and transformation. Technology adoption and household food security, Analyzing Factors Determining Technology Adoption and Sustainability of Impact- A Case of Smallholder Peasants in Nepal. Giessen University press, Germany. PP84.

[2] Cimmyt, (1988). From agronomic data to farmer recommendation: An economic training manual PP 8-37. 
[3] Grover, D. K. and Temesgen, A. (2004). Agricultural technology dissemination program. Alleviating rural poverty through efficient smallholders farming system in Ethiopia: Relevance of macro polices with ground relation. Punjab Agricultural University press, Ludhiana, India. PP 11.

[4] Hazell, P. B. R. and Norton, R. D. (1986). Mathematical programming for economic analysis in agriculture. Macmillan publishing company, University of New Mexico press, New York, USA. PP 1-77.

[5] IFAD, (1999). North Kordofan Rural Development Project (NKRDP) reappraisal report, volume 1: Main report.

[6] Mahmood, K., Subhani, S., Chaudhry, M. and Ghafoor, A. (2000). Impact of various packages of herbicides use on yield of transplanted rice. Department of agricultural economics, University of agriculture, Fiasalabad-38040, Pakistan. J. Agri., vol. 2, no. 12. $\mathrm{P} 1$.

[7] Pomeroy, C., Gough, A., Baker, M. and Hildebrand, P. (2005). The influence of household composition upon a diversified tropical Hillside farming project. (file:// A //: / Huyam.htm). Accessed on 30 March 2005. The Dominican Republic. University of Florida press, PP. 4. 